\title{
Induction of apoptosis by the 16-kDa amino-terminal fragment of the insulin-like growth factor binding protein 3 in human colonic carcinoma cells
}

\author{
AKRAM M. H-ZADEH, TRACEY J. COLLARD, KARIM MALIK, DIANE J. HICKS, \\ CHRIS PARASKEVA and ANN C. WILLIAMS \\ Department of Cellular and Molecular Medicine, Cancer Research UK Colorectal Tumour Biology Group, \\ University of Bristol, School of Medical Sciences, University Walk, Bristol BS8 1TD, UK
}

Received May 15, 2006; Accepted June 28, 2006

\begin{abstract}
The insulin-like growth factor binding protein 3 (IGFBP-3) is the major circulating IGF binding protein, its function regulated by proteolytic cleavage. The fragments generated have recently been suggested to have IGFindependent biological activity. We have previously established that IGFBP-3 can potentiate apoptosis in colorectal epithelial cells, although its use as a therapeutic reagent may be limited by the fact that it is cleaved in the circulation. Therefore the aim of these experiments was to determine whether the $16-\mathrm{kDa}$ proteolytic fragment $\left({ }^{1-95} \mathrm{IGFBP}-3\right)$ would have IGF-independent pro-apoptotic activity in human colonic carcinoma derived cells. We report that the enforced expression of ${ }^{1-95}$ IGFBP-3 increased the induction of apoptosis by the naturally occurring short chain fatty acid sodium butyrate $(\mathrm{NaBt})$ in the IGF non-responsive HT29 human colorectal carcinoma cell line. Furthermore, the addition of condition medium containing the secreted ${ }^{1-95}$ IGFBP-3 was as effective as the intact IGFBP-3 protein at potentiating apoptosis. Although not associated with changes in Bcl-2, $\mathrm{Bcl}-\mathrm{X}_{\mathrm{L}}$, Bax, Bad or Bak expression levels, we report that the expression of the pro-apoptotic ${ }^{1-95}$ IGFBP-3 fragment is associated with the inhibition of $\mathrm{TNF} \alpha$-induced $\mathrm{NF}-\kappa \mathrm{B}$ activity, similar to that reported for the full length IGFBP-3 protein. These results suggest that the $16-\mathrm{kDa}{ }^{1-95} \mathrm{IGFBP}-3$ fragment is as effective as an intact recombinant protein when used in combination with apoptosis inducing agents, and due to its relative stability in the circulation, it may be important for use as an adjuvant in the treatment of colorectal cancer.
\end{abstract}

Correspondence to: Professor Chris Paraskeva, Department of Cellular and Molecular Medicine, Cancer Research UK Colorectal Tumour Biology Group, University of Bristol, School of Medical Sciences, University Walk, Bristol BS8 1TD, UK

E-mail: c.paraskeva@bristol.ac.uk

Key words: insulin like growth factor binding protein 3, ${ }^{1-95}$ IGFBP-3, apoptosis, colorectal carcinogenesis

\section{Introduction}

It has been reported that colorectal cancer risk is positively related to the insulin-like growth factor 1 (IGF-1) and inversely related to insulin-like growth factor binding protein 3 (IGFBP-3) $(1,2)$. The IGFBP-3 protein is a multifunctional protein with a complex physiological role. Evidence suggests that IGFBP-3-induced growth inhibition and/or apoptosis may occur by sequestering and inhibiting IGF binding to its cognate receptor (3). However, IGFBP-3 has also been shown to promote apoptosis through an IGF-independent mechanism (4-7). Previous studies from our group have shown that the addition of human recombinant IGFBP-3 protein can potentiate $\mathrm{p} 53$-dependent $\gamma$-radiation-induced apoptosis in colorectal tumour cells (8) and enhances the sensitivity of colonic adenoma cells to p53-independent apoptosis (9).

Proteolytic modification of IGFBP-3 is thought to be a principal mechanism for regulating not only IGF-1 availability but also the IGF-independent functions of IGFBP-3 (10). Increased IGFBP-3 proteolysis in serum has been reported in cancer (11); in a study of patients with colon cancer, a group with increased IGFBP-3 proteolytic activity suffered fewer metastases than did another with less IGFBP-3 proteolytic activity (12). Three naturally occurring fragments of IGFBP-3 have been detected in human hemofiltrates with molecular mass of 34,16 and $11-\mathrm{kDa}(13)$. The $16-\mathrm{kDa}$ N-terminal fragment has been shown to have virtually no affinity for IGFs (14), and yet is reported to induce potent growth inhibition and/or apoptosis in both human breast cancer cells $(15,16)$ and prostate PC3 cancer cell lines $(17)$.

We have previously established that both the addition of recombinant IGFBP-3 and the enforced expression of IGFBP-3 can potentiate apoptosis in colorectal epithelial cells $(8,9)$, leading to the possibility that IGFBP-3 may be of use as an adjuvant for existing therapies in colorectal cancer. However, one possible difficulty with this approach is that it would be difficult to maintain the therapeutic levels of intact IGFBP-3 protein in the patient, as its levels are tightly regulated through proteolysis. The report that increased IGFBP-3 proteolytic activity correlates with improved prognosis in colon cancer patients (12), suggests that it is 
possible that the IGFBP-3 proteolytic fragments may themselves have pro-apoptotic activity in colorectal cancer cells. Given the potential importance of the IGF system in colorectal cancer, and the fact that there have been no previous studies looking at the affect of IGFBP-3 proteolytic fragments in colorectal cancer cells, the aim of these experiments was to determine whether the ${ }^{1-95}$ IGFBP-3 16-kDa fragment is biologically active in the IGF non-responsive HT29 human colonic carcinoma cell line. In addition, experiments were carried to out to determine the mechanism(s) through which ${ }^{1-95}$ IGFBP-3 may potentiate apoptosis; whether the induction of apoptosis is associated with the regulation of pro-apoptotic (Bax and Bad) to anti-apoptotic (Bcl-2 and $\mathrm{Bcl}-\mathrm{X}_{\mathrm{L}}$ ) proteins (6) and/or inhibition of $\mathrm{NF}-\kappa \mathrm{B}$ survival signalling (18). The purpose is to establish whether the IGFBP-3 fragment (which unlike the intact glycosylated protein is not cleaved in the circulation), could enhance the induction of apoptosis in colorectal tumour cells. This would raise the possibility that the $16-\mathrm{kDa}$ fragment may have potential as a possible therapeutic adjuvant in colorectal cancer.

\section{Materials and methods}

Cell lines, culture media and cell treatment. The human colonic carcinoma derived cell line HT29 was studied. This cell line has a p53 mutation (273 Arg-His), is IGF-1 nonresponsive and has undetectable expression levels of IGFBP-3 (19). For standard growth condition, the HT29 cell line was grown in DMEM (Invitrogen, UK) supplemented with 10\% fetal bovine serum (batch selected), glutamine (2 mM), penicillin $(100 \mathrm{U} / \mathrm{ml})$ and streptomycin $(100 \mu \mathrm{g} / \mathrm{ml})$.

Construction of N-terminal 16-kDa fragment of IGFBP-3. Human IGFBP-3 cDNA in pCP2A was cut with EcoRI restriction enzyme and cloned into the predigested expression vector pCDNA3.1 (Invitrogen). The cDNA of the IGFBP-3 fragment encoding the amino-terminal was generated by PCR amplification from the human IGFBP-3 cDNA using forward primer 5' CGC GGA TCC GGC GTC ATG CAG CGG GCG; and reverse primer 5' CGA ATT CCT AGC GGC TGA CGG CAC TAG (16). BamHI and EcoRI restriction sites were incorporated into the $5^{\prime}$ and $3^{\prime}$ ends of the coding sequence to permit subsequent cloning of the PCR fragment into the expression vector, pcDNA3.1

Transfection of HT29 cells. Sub confluent HT29 cells were transfected with either the full IGFBP-3 cDNA $(2.4 \mathrm{~kb}$, a gift from Professor Jeff Holly, Division of Surgery, Bristol Royal Infirmary, Bristol, UK) or the N-terminal 16-kDa IGFBP-3 cDNA (376 bp) in the pCDNA3.1 expression vector. Cells were transfected using Lipofectamine 2000 (Invitrogen) according to the manufacturer's instructions, and selected using $200 \mu \mathrm{g} / \mathrm{ml} \mathrm{G} 418$ (Sigma). Single colonies were expanded, cell lines established and examined for gene expression at the mRNA and protein levels.

RNA preparation, cDNA synthesis and RT-PCR. Total cellular RNA was isolated using the RNeasy RNA mini kit (Qiagen) according to the manufacturer's instructions. RNA
(1 $\mu \mathrm{g}$ ) was used for cDNA synthesis using the cDNA Synthesis kit (Promega). RT-PCR screening was performed on the HT29 parental cell line, HT29 cells transfected with the empty expression vector and cells transfected with IGFBP-3 or the $16-\mathrm{kDa}{ }^{1-95}$ IGFBP-3 fragment. The primer pairs used in this study for PCR screening were the cloning primers at positions 126-502 of IGFBP-3 cDNA.

Northern blot. Northern analysis of total RNA was carried out using 'Northern Max' kit (Ambion Inc.). The probe was an EcoRI/BamHI fragment of IGFBP-3 which was radiolabelled with $\left[\alpha^{-32} \mathrm{P}\right]$-deoxycytidine triphosphate (Amersham Bioscience) using rediprime II labelling system (Amersham Bioscience). Blots were exposed to Biomax MS film (Kodak) and membranes were then re-probed with a PCR generated fragment of GAPDH, which acted as a loading control for the RNA samples.

Treatment with sodium butyrate (NaBt). Cells were seeded in triplicate flasks and grown under standard growth conditions until $\sim 70 \%$ confluent. Previous investigations showed that HT29 cells were able to tolerate serum-free growth conditions (SFM) for up to $96 \mathrm{~h}$ (SFM = standard non-conditioned growth medium without the addition of FBS) (9). Cells were grown for $24 \mathrm{~h}$ in SFM to remove IGFBP-3 present in the serum and then grown for up to $48 \mathrm{~h}$ in SFM supplemented with or without $4 \mathrm{mM} \mathrm{NaBt}$ (Sigma), previously reported to induce apoptosis (9). Attached and floating (apoptotic, refer below) cell yields were determined from parallel flasks treated for $48 \mathrm{~h}$.

Medium exchange experiments. Sub-confluent monolayers of HT29 cells either expressing IGFBP-3, 16-kDa ${ }^{1-95}$ IGFBP-3 fragment or the empty expression vector were grown for $24 \mathrm{~h}$ in SFM. The cells were then grown for $48 \mathrm{~h}$ in SFM, the media harvested, centrifuged to remove floating cells and stored at $-70^{\circ} \mathrm{C}$. Attached cell numbers were determined using a Neubauer counting chamber (VWR, UK). The secretion of IGFBP-3 or the 16-kDa N-terminal fragment was verified by SDS PAGE immunoblotting, and the proteins detected by anti-IGFBP-3 antiserum (polyclonal from Diagnostic Systems Laboratory). Proteins from the conditioned medium were concentrated (approximately x5) using Millipore Ultrafree-MC filter units and volumes of media loaded onto the gel were adjusted for equivalent cell numbers $\left(5 \times 10^{6}\right.$ cells). Parental HT29 cells were seeded in triplicate flasks and grown under standard growth conditions until $70 \%$ confluent. Cells were grown for $24 \mathrm{~h}$ in SFM and then for up to $48 \mathrm{~h}$ in the conditioned medium from IGFBP-3 or $16-\mathrm{kDa}{ }^{1-95}$ IGFBP-3 expressing HT29 cells $\pm 4 \mathrm{mM} \mathrm{NaBt}$ (Sigma). The conditioned medium from the HT29 cells transfected with the empty vector was used as a control for this study. Attached and floating (apoptotic, refer below) cell yields were determined.

Apoptosis assays. The level of apoptosis was assessed by measuring the proportion of the total cell population that detached from the monolayer and was floating in the medium and by determining the fraction of these floating cells that were apoptotic, as described (8). The attached and floating 
cell populations were stained with $5 \mu \mathrm{g} / \mathrm{ml}$ acridine orange in PBS, and analysed by fluorescent microscopy for morphological features of apoptosis (most obviously the characteristically condensed chromatin, as previously described) $(20,21)$. As the fraction of floating cells that were apoptotic did not vary between the treated and the control untreated cell populations, the number of floating cells could be used as a measure of the induction of apoptosis. Apoptosis was also confirmed by PARP cleavage as previously reported for NaBt treated cells (22).

Bcl-2, Bcl- $X_{L}$, Bad, Bak and Bax protein expression. The levels of Bcl-2, Bcl- $\mathrm{X}_{\mathrm{L}}$, Bad, Bak and Bax were assessed by SDS PAGE immunoblotting, detected by the monoclonal antibodies Bcl-2 (100) Santa Cruz, USA; Bcl-X $\mathrm{L}_{\mathrm{L} / \mathrm{S}}$ (L-10) polyclonal, Santa Cruz; Bad Cell Signaling Technology Inc., USA; Bak Pharmingen (BD) Europe; Bax (n-20) Santa Cruz, respectively) using an ECL detection system (KPL, USA).

$N F-\kappa B$ reporter assays. Cells were transiently transfected with either the NF- $\kappa \mathrm{B}$ reporter plasmid pNF- $\kappa \mathrm{B}-\mathrm{TA}-\mathrm{luc}$ or with the control reporter plasmid pTA-luc (Clontech, BD, Europe). pNF- $\kappa \mathrm{B}-\mathrm{TA}-\mathrm{luc}$ contains four copies of a consensus $\mathrm{NF}-\kappa \mathrm{B}$ binding sequence (GGGAATTTCC) in addition to a minimal promoter $\left(\mathrm{P}_{\mathrm{TA}}\right.$, the TATA box from the herpes simplex virus thymidine kinase promoter) located upstream of the firefly luciferase $(l u c)$ gene. The consensus $\mathrm{NF}-\kappa \mathrm{B}$ binding sequences are absent from the control vector pTAluc. All transfections also included the renilla luciferase vector pRL-SV40 (Promega, UK) as an internal control for transfection efficiency.

For transient transfection, all cells were grown to $70 \%$ confluence in T12.5 flasks. Triplicate flasks were cotransfected with one of the two reporter constructs (pTA-luc or $\mathrm{pNF}-\kappa \mathrm{B}-\mathrm{TA}-\mathrm{luc}$ ) and with the renilla construct (pRLSV40) in a ratio of 50:1. Each flask was incubated for $6 \mathrm{~h}$ with $2 \mu \mathrm{g}$ of plasmid DNA and $5 \mu$ l of Lipofectamine 2000 (Invitrogen) diluted in Opti-MEM serum-free medium according to manufacturer's instructions. Following transfection, cells were allowed to recover overnight prior to $24 \mathrm{~h}$ treatment with $\mathrm{TNF} \alpha(100 \mathrm{ng} / \mathrm{ml}$ for $24 \mathrm{~h})$ in SFM.

Luciferase reporter assay. Twenty-four hours after treatment, cells were washed in PBS and lysates prepared in 1X PLB (Promega, UK) according to manufacturer's instructions. Reporter activity was measured using the Dual-Luciferase reporter assay system (Promega) and a Jade Luminometer (Labtech, UK) set for a $10 \mathrm{sec}$ read. Sample readings were corrected for background autoluminescence using untransfected cells as a control.

Statistical analysis. The data represents the mean of 3 separate experiments (each experiment was carried out in triplicate parallel flasks). Statistical analysis was carried out using SPSS for Windows statistical software (release 10.0.5, SPSS Inc. Chicago, IL, USA). Two-way analysis of variance (ANOVA) was used to determine the differences amongst the means. Pairwise comparisons were made using Tukey's post hoc test for multiple comparisons.

\section{Results}

Expression of IGFBP-3 or the 16-kDa ${ }^{1-95}$ IGFBP-3 fragment in the HT29 carcinoma cell line. HT29 cells were stably transfected with either intact IGFBP-3 or the ${ }^{1-95}$ IGFBP-3 fragment, and expression was determined by RT-PCR, Northern hybridization and Western blotting. Results are summarized in Fig. 1. The PCR products (Fig. 1A) were generated using the same 5' to $3^{\prime}$ oligonucleotide primers as designed for the N-terminus of IGFBP-3 cDNA; hence a 376 bp product (confirmed by sequence analysis, data not shown) was generated in the cells expressing either the whole gene or the ${ }^{1-95}$ IGFBP-3 fragment. No amplification of IGFBP-3 sequences was found in parental or in cells transfected with the empty expression vector (vector control cells). To further confirm expression, the intact IGFBP-3 and ${ }^{1-95}$ IGFBP-3 transcripts were detected by Northern analysis using the PCR generated fragment as the probe (Fig. 1B). Once again there was no detectable mRNA of endogenous IGFBP-3 in the parental and vector control cells; these findings are consistent with the published data showing non-expression or very low expression of IGFBP-3 in the HT29 cell line $(9,19)$. In addition, secreted IGFBP-3 derived proteins from transfected cells could be detected by Western analysis [the 16-kDa ${ }^{1-95}$ IGFBP-3 fragment in Fig. 1C(i) and 42-kDa IGFBP-3 protein in Fig. 1C(ii)].

IGFBP-3 or the 16-kDa ${ }^{1-95}$ IGFBP-3 fragment increases sodium butyrate-induced apoptosis in HT29 cells. Sodium butyrate $(\mathrm{NaBt})$ is a naturally occurring short chain fatty acid which has been shown to induce apoptosis in colorectal epithelial cells (20). It has been proposed that $\mathrm{NaBt}$ may have potential as a chemopreventive/therapeutic agent for colorectal cancer, and that IGFBP-3 may act as a positive regulator of $\mathrm{NaBt}$-induced apoptosis in colonic epithelial cells (9). The aim was to investigate whether HT29 cells expressing either the whole IGFBP-3 protein or the $16-\mathrm{kDa}$ $\mathrm{N}$-terminal fragment were more sensitive to NaBt-induced apoptosis than vector control cells. The results are summarized in Fig. 2. Enforced expression of the ${ }^{1-95}$ IGFBP-3 fragment significantly enhanced $\mathrm{NaBt}$-induced apoptosis as compared to the vector control cells. Similar results were obtained when compared to the parental cell line (data not shown). Importantly, the expression of the ${ }^{1-95}$ IGFBP- 3 fragment was as potent as the whole IGFBP-3 protein at increasing NaBtinduced apoptosis in HT29 cancer cells.

We then assessed whether protein secreted from the HT29 transfected cells (either IGFBP-3 or the 16-kDa ${ }^{1-95}$ IGFBP-3 fragment) could increase NaBt-induced apoptosis in the parental non-transfected cell line. HT29 cells were grown to $70 \%$ confluence and treated with $4 \mathrm{mM} \mathrm{NaBt}$ in conditioned medium from the IGFBP-3 or $16-\mathrm{kDa}{ }^{1-95}$ IGFBP-3 expressing cells. Conditioned medium from the vector control cells was added to the parental HT29 cell cultures as a control for the experimental procedure. The results are summarized in Fig. 3. Both the IGFBP-3 and the ${ }^{1-95}$ IGFBP-3 secreted proteins in the $\mathrm{CM}$ significantly increased $\mathrm{NaBt}$-induced apoptosis $(\mathrm{P}<0.01)$. Once again, the fragment was as potent as the whole IGFBP-3 protein at increasing apoptosis. 


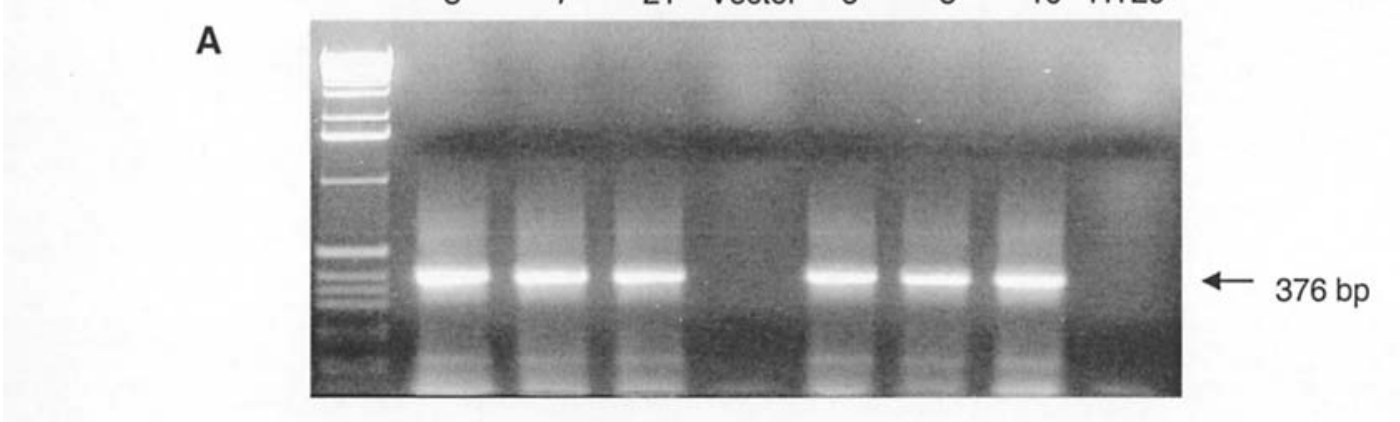
TT29 IGFBP-3

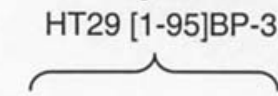

3
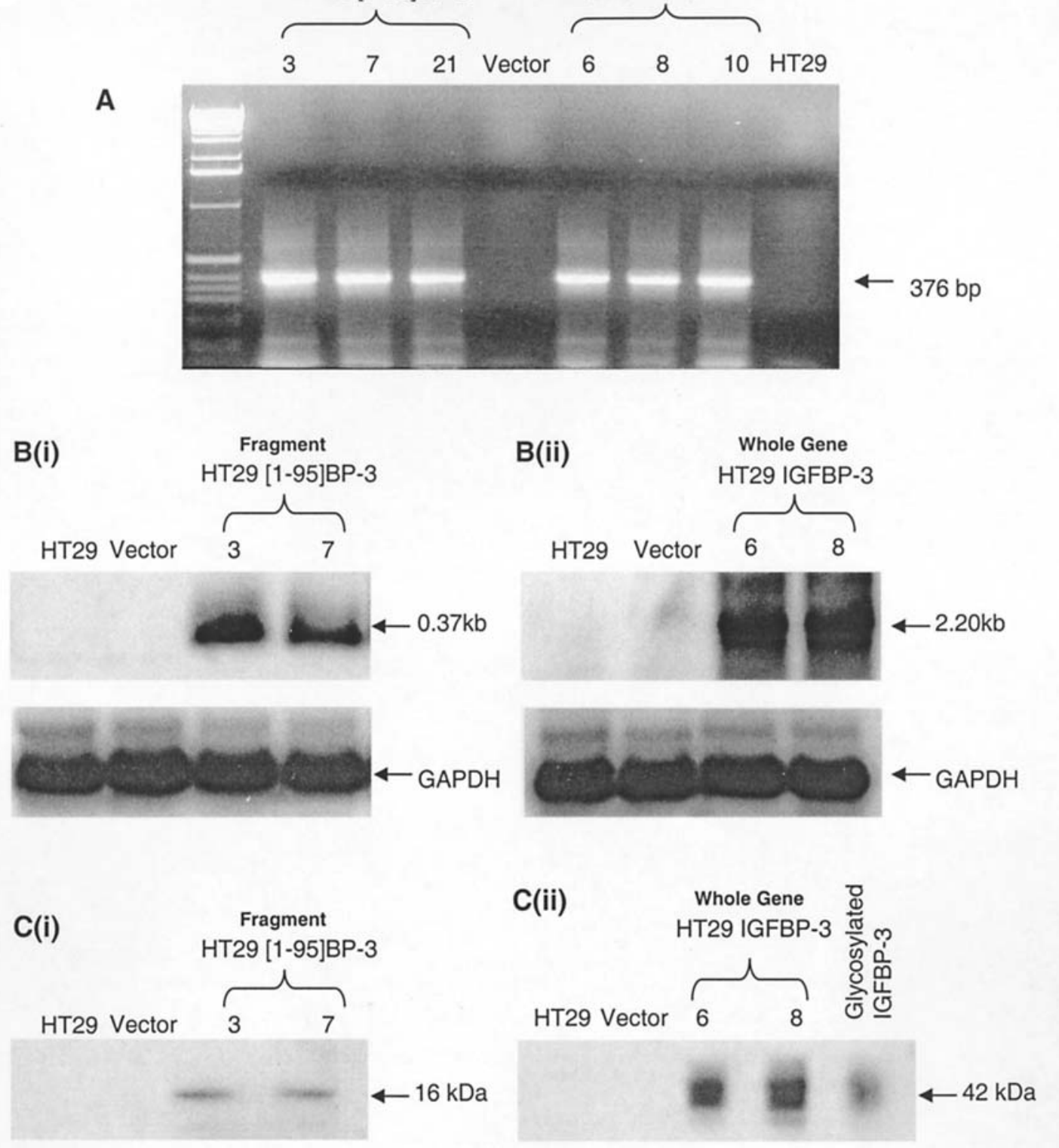

Figure 1. Expression of the16-kDa ${ }^{1-95}$ IGFBP-3 fragment or IGFBP-3 in HT29 cells. (A) Expression of the16-kDa ${ }^{1-95}$ IGFBP-3 fragment or IGFBP-3 in HT29 cells as shown by RT-PCR. Using primers which amplify N-terminal sequences, the expression of the whole gene or 16-kDa fragment was detected in independent clones isolated after transfection with either the 16-kDa ${ }^{1-95}$ IGFBP-3 fragment (results for 3 independent clones) or IGFBP-3 cDNA (results for 3 independent clones). No expression was detected either in the HT29 cells transfected with the empty expression vector or the parental HT29 cell line. Molecular weight markers are shown in lane 1. Numbers above lanes denote individual clones analysed. (B) Northern analysis to show 1-95IGFBP-3 or IGFBP-3 mRNA expression in HT29 transfected cells. (i) Expression of the 16-kDa ${ }^{1-95}$ IGFBP-3 fragment [(1-95)BP-3]. (ii) Expression of the exogenous whole IGFBP-3. Results are presented for 2 independent clones. GAPDH was used to control for RNA loading. (C) Western blot showing the 16-kDa ${ }^{1-95}$ IGFBP-3 fragment or intact IGFBP-3 protein secreted by transfected HT29 cells. Aliquots of 5x concentrated conditioned serum free medium from 5x10 6 transfected cells were analysed by SDS-PAGE, the protein detected by anti-IGFBP-3 antiserum. (i) Expression of the N-terminal ${ }^{1-95}$ IGFBP-3 protein fragment (16-kDa). (ii) Expression of the IGFBP-3 protein $(42-\mathrm{kDa})$. No protein was detected in conditioned medium from the parental or vector control cell lines. (Glycosylated IGFBP-3 (100 ng) (Gropep, Aus) is shown as a control. IGFBP-3 resolves as a number of bands on electrophoresis, representing post-trancriptionally modified protein (9). Numbers above lanes denote individual clones analysed.

Taken together these results demonstrate that the $16-\mathrm{kDa}$ $\mathrm{N}$-terminal fragment $\left({ }^{1-95} \mathrm{IGFBP}-3\right)$ is a pro-apoptotic regulator in human carcinoma derived colorectal epithelial cells. In addition, the ${ }^{1-95}$ IGFBP-3 fragment is as potent as the whole IGFBP-3 protein at increasing both spontaneous and NaBt-induced apoptosis in the HT29 cell line.

IGFBP-3 but not the 16-kDa ${ }^{1-95}$ IGFBP-3 fragment inhibits $\mathrm{Bcl}-2$ expression in HT29 cells. IGFBP-3 has previously been suggested to favour apoptosis by increasing the ratio of proapoptotic (Bax and Bad) to anti-apoptotic (Bcl-2 and Bcl- $\mathrm{X}_{\mathrm{L}}$ ) proteins in breast cancer cells (6). To elucidate the mechanism through which the ${ }^{1-95}$ IGFBP-3 fragment increases apoptosis, the levels of Bcl-2, Bcl- $\mathrm{X}_{\mathrm{L}}$, Bax, Bak or Bad were determined and the results summarized in Fig. 4A. Neither enforced expression of IGFBP-3 nor the 16-kDa NBP-3 fragment had any effect on the level of $\mathrm{Bcl}-\mathrm{X}_{\mathrm{L}}, \mathrm{Bax}, \mathrm{Bak}$ or $\mathrm{Bad}$ protein expression. However, expression of the whole IGFBP-3 did 
A

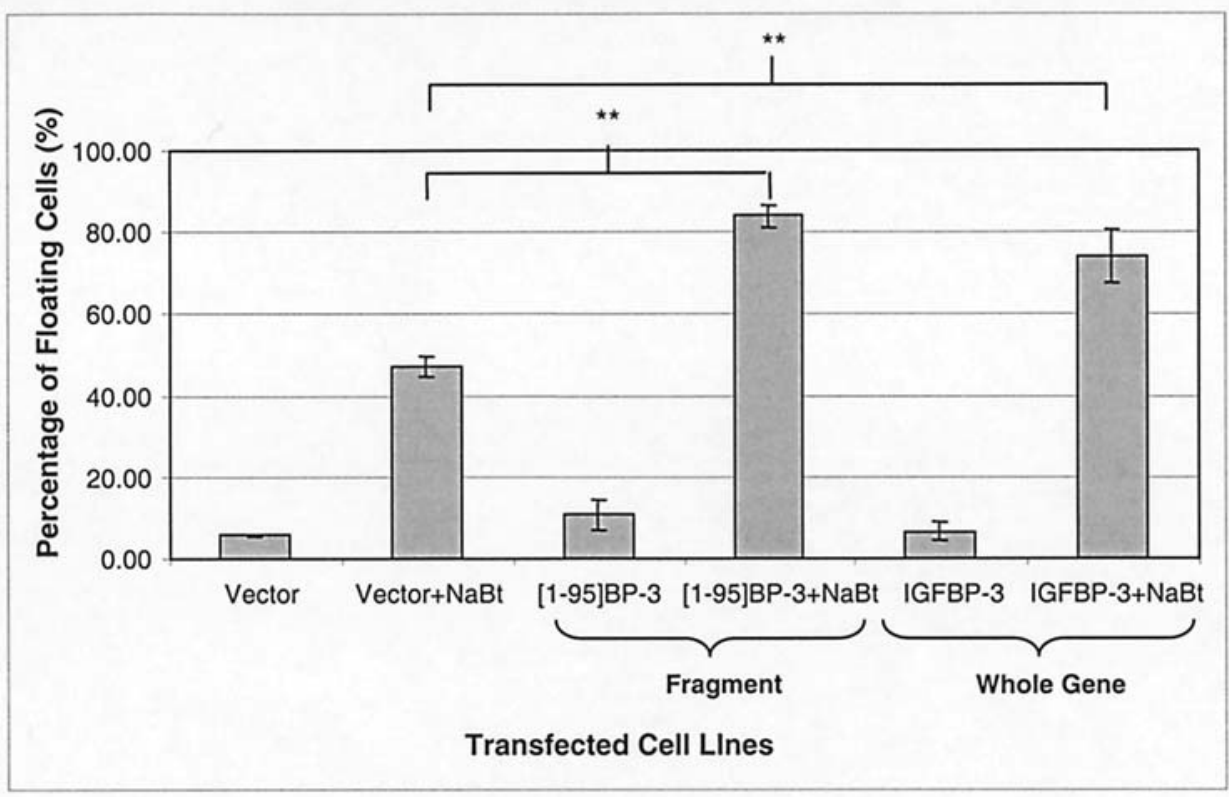

$B(i)$

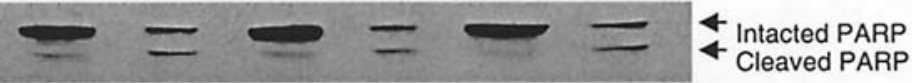

B(ii)
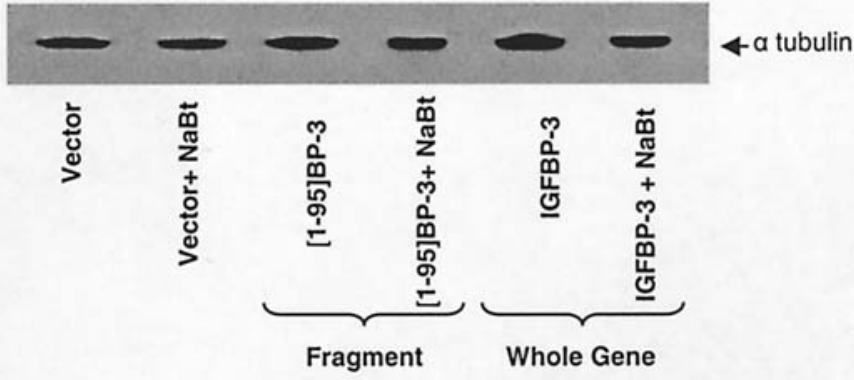

C(i)

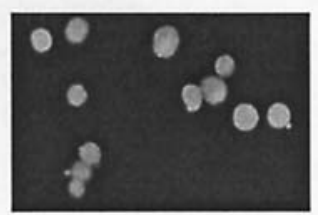

C(ii)

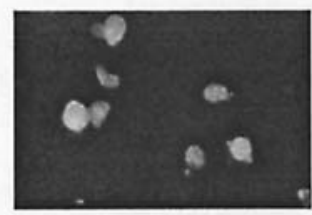

C(iii)

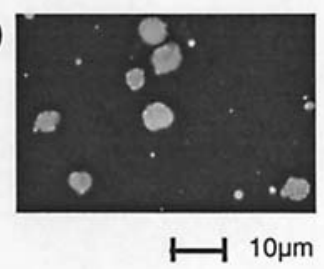

Figure 2. IGFBP-3 and the 16-kDa ${ }^{1-95}$ IGFBP-3 fragment increase sodium butyrate-induced apoptosis in HT29 cells. (A) Induction of apoptosis in the HT29 carcinoma derived cell line stably expressing either the 16-kDa ${ }^{1-95}$ IGFBP-3 fragment [(1-95)BP-3] or the whole protein (IGFBP-3) after 48 h treatment with $4 \mathrm{mM} \mathrm{NaBt}$ in SFM. The results shown are the mean of 3 separate experiments \pm SEM, statistical difference determined by two way ANOVA with replication, ${ }^{*} \mathrm{P}<0.05,{ }^{* *} \mathrm{P}<0.01,{ }^{* * *} \mathrm{P}<0.001$. (B) Western blot showing (i) PARP expression and (ii) $\alpha$-tubulin (loading control), in mixed attached and floating HT29 cell populations $48 \mathrm{~h}$ after treatment $\pm \mathrm{NaBt}(4 \mathrm{mM})$. Cleavage of PARP in the NaBt treated cells indicates induction of apoptosis above spontaneous levels. (C) Acridine orange staining of mixed attached and floating HT29 cells from the NaBt treated (i) vector control, (ii) ${ }^{1-95}$ IGFBP-3-expressing [(1-95)BP-3], and (iii) IGFBP-3 expressing cell populations, showing the morphological characteristics of apoptosis.

significantly suppress Bcl-2 protein expression in HT29 cells, although it should be stressed that this was not seen in other human colorectal adenoma $(\mathrm{S} / \mathrm{RG} / \mathrm{C} 2)$ or carcinoma (SW480) derived cell lines tested, where expression of Bcl-2, Bcl-X $\mathrm{L}_{\mathrm{L}}$, Bax, Bak or Bad did not change (data not shown). In contrast, the expression of the 16-kDa ${ }^{1-95}$ IGFBP-3 fragment had no effect on Bcl-2 protein expression (Fig. 4A).

The 16-kDa ${ }^{1-95}$ IGFBP-3 fragment inhibits $N F \kappa B$ activity in TNF $\alpha$-treated HT29 cells. We have recently reported that
IGFBP-3 can potentiate apoptosis through inhibition of the $\mathrm{NF}-\kappa \mathrm{B}$ survival pathway (18). The aim of this investigation was to determine whether the expression of the ${ }^{1-95}$ IGFBP-3 fragment also inhibited $\mathrm{NF}-\kappa \mathrm{B}$ activation. As the death receptor mediated apoptotic signalling results in concurrent activation of the NF- $\mathrm{KB}$ survival pathway (23), we used a reporter assay to determine $\mathrm{NF}-\mathrm{\kappa B}$ activation in the $16-\mathrm{kDa}$ ${ }^{1-95}$ IGFBP-3-expressing HT29 cells treated with TNF $\alpha$ (100 $\mathrm{ng} / \mathrm{ml}$ for $24 \mathrm{~h}$ ). The results are summarized in Fig. 4B. Expression of the ${ }^{1-95}$ IGFBP-3 fragment suppresses NF-кB 


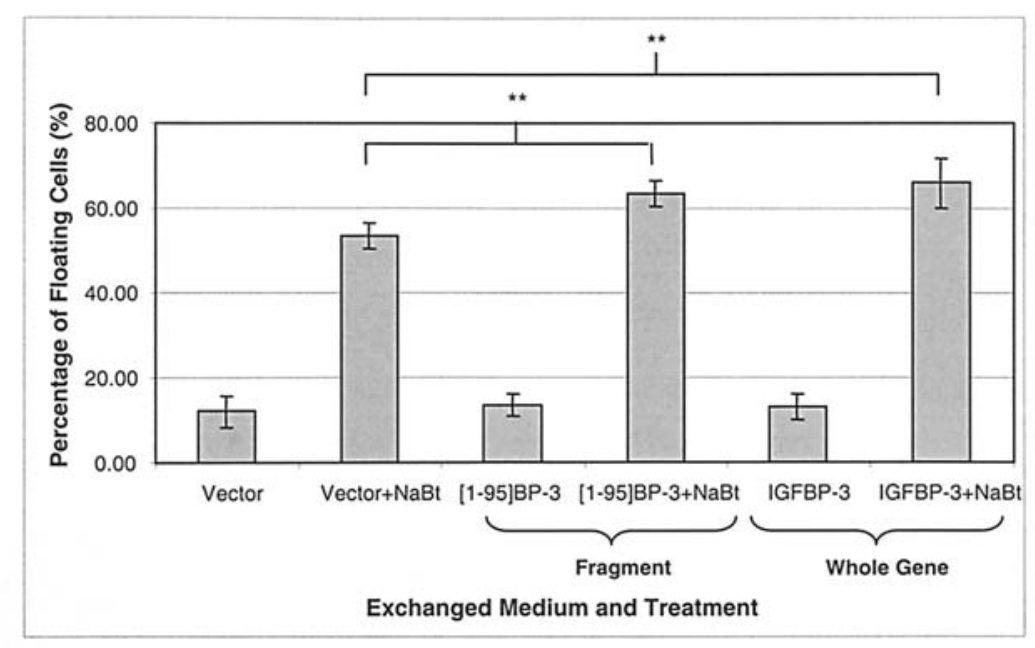

Figure 3. Addition of IGFBP-3 protein or the 16-kDa ${ }^{1-95}$ IGFBP-3 fragment increases NaBt-induced apoptosis in the parental non-transfected HT29 cell line. Induction of apoptosis in the parental HT29 carcinoma derived cell line after $48 \mathrm{~h}$ treatment with conditioned medium containing either the $16-\mathrm{kDa}{ }^{1-95}$ IGFBP-3 fragment [(1-95)BP-3 CM] or the whole IGFBP-3 protein (IGFBP-3 CM) $\pm 4 \mathrm{mM} \mathrm{NaBt}$. The results shown are the mean of 3 separate experiments \pm SEM, statistical difference determined by two way ANOVA with replication, ${ }^{*} \mathrm{P}<0.05,{ }^{* *} \mathrm{P}<0.01,{ }^{* * *} \mathrm{P}<0.001$. The conditioned medium from the HT29 cells transfected with the empty vector was used as a control for this study. Cells were confirmed as apoptotic by changes in morphology as detected by acridine orange staining and cleavage of PARP as described in detail previously $(9,18)$ (data not shown).

A

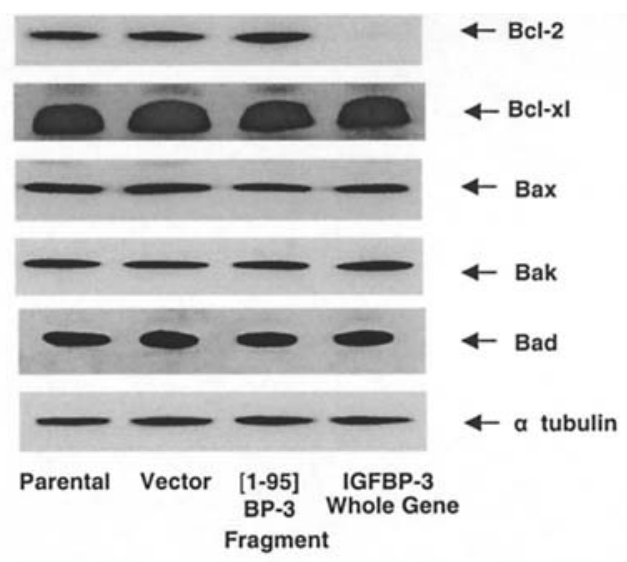

B

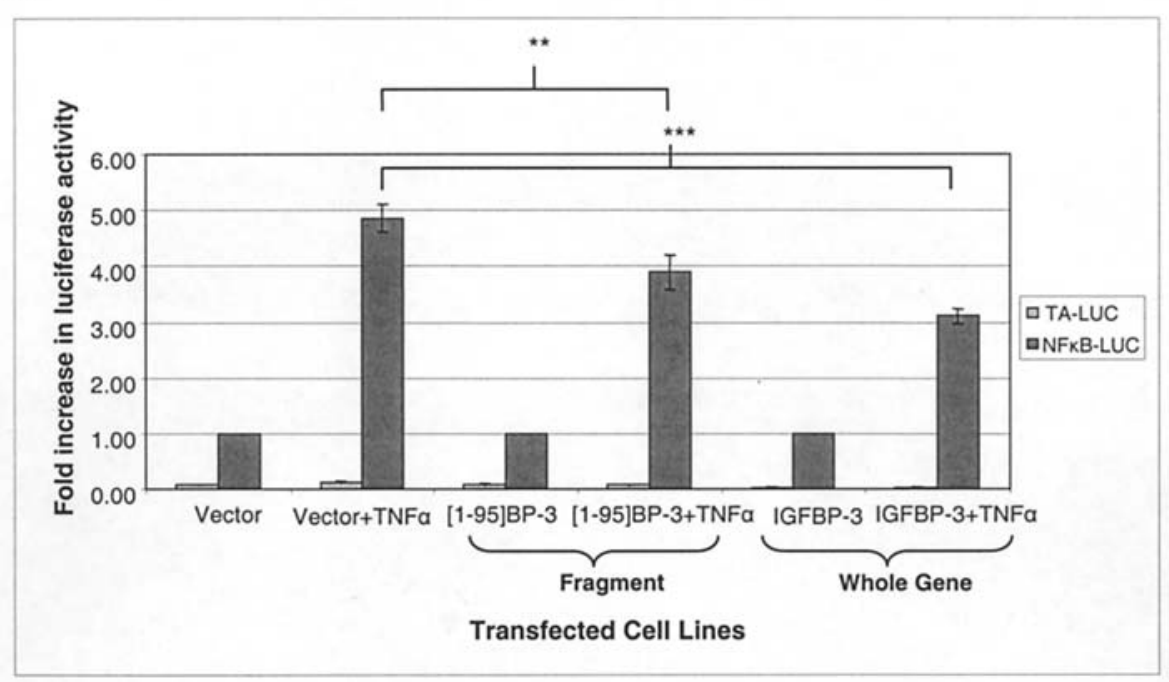

Figure 4. (A) IGFBP-3 but not the 16-kDa ${ }^{1-95}$ IGFBP-3 fragment inhibits Bcl-2 expression in HT29 cells. Western blot showing Bcl-2, Bcl-xl, Bax, Bak, Bad and $\alpha$-tubulin (loading control) protein expression in HT29 cells expressing the 16-kDa ${ }^{1-95}$ IGFBP-3 fragment [(1-95)BP-3] or the whole IGFBP-3 protein (IGFBP-3). Expression levels are compared to vector control and non-transfected parental HT29 cells. (B) IGFBP-3 and the 16-kDa ${ }^{1-95}$ IGFBP-3 fragment inhibit NF-kB activity in TNF $\alpha$-treated HT29 cells. The effect of enforced expression of the 16-kDa ${ }^{1-95}$ IGFBP-3 fragment [(1-95)BP-3] or the whole IGFBP-3 protein (IGFBP-3) on NF-kB activation in TNF $\alpha$-treated (100 ng/ml for $24 \mathrm{~h}$ ) HT29 cells. pNF-kB-TA-luc:firefly renilla ratios are expressed as a percentage of vector only untreated cells, results shown are representative of 4 independent experiments \pm SEM, statistical difference determined by two way ANOVA with replication, ${ }^{*} \mathrm{P}<0.05,{ }^{* *} \mathrm{P}<0.01,{ }^{* * *} \mathrm{P}<0.001$. 
activation, suggesting that the pro-apoptotic activity of the $16-\mathrm{kDa}{ }^{1-95}$ IGFBP-3 fragment may also be mediated through the inhibition of the NF- $\mathrm{BB}$ survival pathway.

\section{Discussion}

In the current study we show that the enforced expression of the ${ }^{1-95}$ IGFBP-3 fragment is able to increase the sensitivity of HT29 cells to the induction of apoptosis by NaBt treatment. As HT29 cells have mutant p53 protein expression (24) and are IGF non-responsive (19), this induction of apoptosis is both p53 and IGF-1-independent. Furthermore, as cellassociation sites have not been reported in the amino terminus of IGFBP-3, the inhibitory effects of ${ }^{1-95}$ IGFBP-3 may involve the internalization of the protein and subsequent intracellular actions (15). Significantly, we have demonstrated that the ${ }^{1-95}$ IGFBP-3 amino fragment has a proapoptotic function equivalent to that of the whole protein in colorectal cancer cells.

The mechanism through which the $16-\mathrm{kDa}{ }^{1-95} \mathrm{IGFBP}-3$ fragment of IGFBP-3 increases apoptosis remains unclear. Previous reports have suggested that IGFBP-3 may favour apoptosis by increasing the ratio of pro-apoptotic (Bax and $\mathrm{Bad}$ ) to anti-apoptotic (Bcl-2 and $\mathrm{Bcl}-\mathrm{X}_{\mathrm{L}}$ ) proteins (6). However, in the current study neither the enforced expression of IGFBP-3 nor the 16-kDa ${ }^{1-95}$ IGFBP-3 fragment had any effect on the level of $\mathrm{Bax}, \mathrm{Bad}, \mathrm{Bak}$ or $\mathrm{Bcl}-\mathrm{X}_{\mathrm{L}}$ protein expression. Expression of the whole IGFBP-3 protein did significantly suppress Bcl-2 protein expression in HT29 cells (although not in other human colorectal cell lines). In contrast, the expression of the 16-kDa ${ }^{1-95}$ IGFBP-3 fragment had no effect on $\mathrm{Bcl}-2$ protein expression. The significance of this finding remains unknown; whereas increased apoptotic susceptibility mediated by IGFBP-3 protein(s) may be attributed in part to the regulation of the $\mathrm{Bcl}-2$ protein family in a subset of tumours, the molecular mechanism underlying the increased susceptibility in the ${ }^{1-95}$ IGFBP-3 expressing cells was not due to suppression of $\mathrm{Bcl}-2$ expression. However, expression of the $16-\mathrm{kDa}{ }^{1-95} \mathrm{IGFBP}-3$ fragment was shown to suppress NF- $\mathrm{BB}$ activation (as does the whole protein) (18) and therefore we propose that the pro-apoptotic activity of the $16-\mathrm{kDa}{ }^{1-95}$ IGFBP-3 fragment may also be mediated through the suppression of the NF- $\mathrm{KB}$ survival pathway. As $\mathrm{NaBt}$ has previously been reported to induce apoptosis at least in part through the inhibition of constitutive NF- $\mathrm{KB}$ activity in cancer cells $(25,26)$, data presented here would suggest that both IGFBP-3 and the $16-\mathrm{kDa}{ }^{1-95}$ IGFBP-3 fragment could potentiate NaBt-induced cell death through acting synergistically with $\mathrm{NaBt}$, to suppress NF- $\kappa$ B activity.

IGFBP-3 has previously been proposed as a possible adjuvant to existing cancer therapy, although one potential difficulty with the therapeutic use of IGFBP-3 is proteolysis of the whole protein in the circulation and cell environment (10). Results from this study suggest that the addition of the proteolytic N-terminal fragment of IGFBP-3 may be as effective as the whole protein in enhancing the induction of apoptosis, with the advantage that it has low affinity and hence would not disrupt IGF signalling in normal tissues. Another advantage in administering the ${ }^{1-95}$ IGFBP-3 fragment rather than the whole protein is that, although proteolysis of IGFBP-3 would increase the levels of the $16-\mathrm{kDa}$ fragment, it also yields a number of other protein fragments, the largest of which (22-25 kDa) may have opposing action to the $16-\mathrm{kDa}$ ${ }^{1-95}$ IGFBP-3 fragment, as they have been reported to induce cell growth in prostate cancer cells (17). In summary, we have shown for the first time that the N-terminal $16-\mathrm{kDa}$ fragment of IGFBP-3 ( ${ }^{1-95}$ IGFBP-3) enhances the effect of apoptosis-inducing agents in colon carcinoma cells in vitro and suggest that ${ }^{1-95}$ IGFBP-3 could play a role in increasing the actions of anticancer drugs in vivo.

\section{Acknowledgements}

This study was funded by Cancer Research UK and the Citrina Foundation.

\section{References}

1. Ma J, Pollak MN, Giovannucci E, Chan JM, Tao Y, Hennekens $\mathrm{CH}$ and Stampfer MJ: Prospective study of colorectal cancer risk in men and plasma levels of insulin-like growth factor (IGF)-I and IGF-binding protein-3. J Natl Cancer Inst 91: 620-625, 1999.

2. Giovannucci E, Pollak MN, Platz EA, Willett WC, Stampfer MJ, Majeed N, Colditz GA, Speizer FE and Hankinson SE: A prospective study of plasma insulin-like growth factor-1 and binding protein-3 and risk of colorectal neoplasia in women. Cancer Epidemiol Biomarkers Prev 9: 345-349, 2000.

3. Jones JI and Clemmons DR: Insulin-like growth factors and their binding proteins: Biological actions. Endocr Rev 16: 3-34, 1995.

4. Rajah R, Valentinis B and Cohen P: Insulin-like growth factor (IGF)-binding protein-3 induces apoptosis and mediates the effects of transforming growth factor- $\beta 1$ on programmed cell death through a p53- and IGF-independent mechanism. J Biol Chem 272: 12181-12188, 1997.

5. Gill Z, Perks C, Newcomb P and Holly JM: Insulin-like growth factor binding protein 3 (IGFBP-3) predisposes breast cancer cell lines to programmed cell death in a non-IGF-dependent manner. J Biol Chem 272: 25602-25607, 1997.

6. Butt AJ, Firth SM, King MA and Baxter RC: Insulin-like growth factor-binding protein-3 modulates expression of Bax and $\mathrm{Bcl}-2$ and potentiates p53-independent radiation-induced apoptosis in human breast cancer cells. J Biol Chem 275: 39174-39181, 2000

7. Butt AJ and Williams AC: IGFBP-3 and apoptosis - a license to kill? Apoptosis 6: 199-205, 2001.

8. Williams AC, Collard TJ, Perks CM, Newcomb P, Moorghen M, Holly JMP and Paraskeva C: Increased p53-dependent apoptosis by the insulin-like growth factor binding protein IGFBP-3 in human colonic adenoma-derived cells. Cancer Res 60: 22-27, 2000.

9. Collard TJ, Guy M, Butt AJ, Perks CM, Holly JMP, Paraskeva C and Williams AC: Transcriptional up-regulation of the insulinlike growth factor binding protein IGFBP-3 by sodium butyrate increases IGF-independent apoptosis in human colonic adenoma-derived epithelial cells. Carcinogenesis 24: 393-401, 2003.

10. Firth SM and Baxter RC: Cellular actions of the insulin-like growth factor binding proteins. Endocr Rev 23: 824-854, 2002 .

11. Bunn RC and Fowlkes JL: Insulin-like growth factor binding protein proteolysis. Trends Endocr Metab 14: 176-181, 2003.

12. Baciuchka M, Remacle-Bonnet M, Garrouste F, Favre R, Sastre B and Pommier G: Insulin-like growth factor (IGF)-binding protein-3 (IGFBP-3) proteolysis in patients with colorectal cancer: Possible association with the metastatic potential of the tumor. Int J Cancer 79: 460-467, 1998.

13. Kubler B, Draeger C, John H, Andag U, Scharf JG, Forssmann WG, Braulke $\mathrm{T}$ and Standker L: Isolation and characterization of circulating fragments of the insulin-like growth factor binding protein-3. FEBS Lett 518: 124-128, 2002. 
14. Lalou C, Lassarre C and Binoux M: A proteolytic fragment of insulin-like growth factor (IGF) binding protein-3 that fails to bind IGFs inhibits the mitogenic effects of IGF-I and insulin. Endocrinology 137: 3206-3212, 1996.

15. Salahifar H, Firth SM, Baxter RC and Martin JL: Characterization of an amino-terminal fragment of insulin-like growth factor binding protein-3 and its effects in MCF-7 breast cancer cells. Growth Horm IGF Res 10: 367-377, 2000.

16. Bernard L, Babajko S, Binoux M and Ricort JM: The aminoterminal region of insulin-like growth factor binding protein-3, ${ }_{1-95}$ IGFBP-3, induces apoptosis of MCF-7 breast carcinoma cells. Biochem Biophys Res Commun 293: 55-60, 2002.

17. Angelloz-Nicoud P, Lalou C and Binoux M: Prostate carcinoma (PC-3) cell proliferation is stimulated by the $22-25-\mathrm{kDa}$ proteolytic fragment $(1-160)$ and inhibited by the $16-\mathrm{kDa}$ fragment $(1-95)$ of recombinant human insulin-like growth factor binding protein-3. Growth Horm IGF Res 8: 71-75, 1998.

18. Williams AC, Smartt H, H-Zadeh AM, MacFarlane M, Paraskeva $\mathrm{C}$ and Collard TJ: Insulin-like growth factor binding protein (IGFBP-3) potentiates TRAIL-induced apoptosis of human colorectal carcinoma cells through inhibition of NF-кB. Cell Death Differ: Epub ahead of print, 2006.

19. Singh P, Dai B, Yallampalli C and Xu Z: Expression of IGF-II and IGF-binding proteins by colon cancer cells in relation to growth response to IGFs. Am J Physiol 267: G608-G617, 1994.
20. Hague A, Manning AM, Hanlon KA, Huschtscha LI, Hart D and Paraskeva C: Sodium butyrate induces apoptosis in human colonic tumour cell lines in a p53-independent pathway implications for the possible role of dietary fibre in the prevention of large-bowel cancer. Int J Cancer 55: 498-505, 1993.

21. Tsujii $\mathrm{M}$ and DuBois RN: Alterations in cellular adhesion and apoptosis in epithelial cells overexpressing prostaglandin endoperoxide synthase 2. Cell 83: 493-501 1995.

22. Crew TE, Elder DJ and Parakeva C: A cyclooxygenase-2 (COX-2) selective non-steroidal anti-inflammatory drug enhances the growth inhibitory effect of butyrate in colorectal carcinoma cells expressing COX-2 protein: regulation of COX2 by butyrate. Carcinogenesis 21: 69-77, 2000.

23. Harper N, Farrow SN, Kaptein A, Cohen GM and MacFarlane M: Modulation of tumor necrosis factor apoptosis-inducing ligandinduced NF-B activation by inhibition of apical caspases. J Biol Chem 276: 34743-34752, 2001.

24. Rodrigues N, Rowan A, Smith MEF, Kerr IB, Bodmer WF, Gannon JV and Lane DP: p53 mutations in colorectal cancer. Proc Natl Acad Sci USA 87: 7555-7559, 1990.

25. Inan MS, Rasoulpour RJ, Yin L, Hubbard AK, Rosenberg DW and Giardina C: The luminal short-chain fatty acid butyrate modulates NF- $\mathrm{KB}$ activity in a human colonic epithelial cell line. Gastroenterology 118: 798-801, 2000.

26. Rouet-Benzineb P, Aparicio T, Guilmeau S, Pouzet C, Descatoire V, Buyse $\mathrm{M}$ and Bado A: Leptin counteracts sodium butyrate-induced apoptosis in human colon cancer HT-29 cells via NF-кB signaling. J Biol Chem 279: 16495-502, 2004. 